\title{
Distinguishing cartoon subgenres based on a multicultural contemporary corpus
}

\author{
Ana Pedrazzini \\ CyC IPEHCS Consejo Nacional de Investigaciones Científicas y Técnicas - Universidad Nacional del \\ Comahue \\ ana.pedrazzini@crub.uncoma.edu.ar
}

\author{
Nora Scheuer \\ CyC IPEHCS Consejo Nacional de Investigaciones Científicas y Técnicas - Universidad Nacional del \\ Comahue \\ nora.scheuer@gmail.com
}

\begin{abstract}
A literature review reveals the lack of empirical and theoretical work dedicated to systematically grasping the diversity of cartoons. Most studies have focused on political and/or editorial cartoons and have neglected other subgenres, which however are gaining space in many forms of media-such as gag cartoons. Taking genre discursive studies as a starting point, this paper is aimed at distinguishing cartoon subgenres considering their modal, thematic, pragmatic and rhetorical features. The corpus is composed of 85 cartoons (51 multimodal and 34 solely visual) from 22 countries. This corpus was obtained by means of a questionnaire distributed over 2012-2016 in which cartoonists were asked to choose a cartoon that represented their style and to justify their choice. A combination of both qualitative and multivariate statistical techniques was applied. Results allowed us to distinguish four cartoon subgenres based mostly on thematic and pragmatic features: Daily political; Timeless political; Daily media, arts and sports; and Playful cartoons. From a rhetorical standpoint, Timeless political cartoons showed the highest semiotic density (8-12 resources per cartoon), Daily political cartoons an intermediate density (5-7 resources per cartoon) and Playful cartoons the lowest semiotic density (2-4 resources). This contrast might indicate a difference in the cognitive challenge posed to readers, with a major cognitive effort demanded by political cartoons (Timeless and Daily), in addition to the necessary awareness of current affairs. In line with previous research, metaphor appeared as a characteristic resource in political cartoons followed by irony, sarcasm and allusion. Modal analyses showed that political cartoons relied more on the verbal mode to build their messages than the other subgenres.
\end{abstract}

Keywords: cartoon; genre; topic; rhetorical resources; pragmatics. 


\section{Introduction}

Cartoons consist of a schematic and condensed text, often reduced to a single-panel published in the press, in which cartoonists deploy a wide range of resources in order to comment on social/political issues, events or personalities. Borrowed from the French carton, itself from the Italian cartone, the term cartoon is introduced in England in 1843 to designate humorous drawings published in the press, by the magazine Punch (see Online Etymology Dictionary; also El Refaie 2009; Harvey 2009). More recent meanings of the term include cartoon illustrations usually published in books or magazines for children and animated cartoons (Harrison 1981 quoted by Bivins 1984).

The mobile and heterogeneous nature of press cartoons has been highlighted by some scholars. In this direction, Tillier (2005: 10) refers to cartoons as a "plural object and a "particular genre"" and points at a "lexical floating" (2005: 14) which is evidenced in the unsystematic use of a variety of terms, such as humorous cartoon, graphic satire, political caricature and current or daily cartoon (our translation from French). A certain degree of conceptual overlapping underlies this lexical floating. This situation brings to light the fact that there is still work to be done so that the boundaries within the heterogeneous field of cartoons are more clearly identified.

The aforementioned "lexical floating" is also evident through the unclear difference between political and editorial cartoons, with the latter being mostly political itself. Indeed, both terms are usually used interchangeably, even if the expression "political cartoon" brings forth the theme addressed in the cartoon, while "editorial cartoon" highlights the cartoonist's pragmatic motivation, expressed in terms of journalistic genres.

Most studies in the academic field have restricted their scope to political or editorial cartoons, to such an extent that many scholars refer to them almost as a synonym of the cartoon genre. A more moderate position confers to political cartoon the status of a discursive genre on its own (for instance El Refaie 2009; Negro Alousque 2013; Ying-Yu Lin \& Chiang 2015). One way or another, such dominance has resulted in the omission of other types of cartoons as a noteworthy object of research. This is the case of the gag, i.e. mostly playful cartoon (Shultz \& Germeroth 1998), despite its increasing presence in Western media (El Refaie 2009) and the importance some scholars have attributed to it. For instance, according to Harvey (2009: 35), gag cartoon "is the haiku of cartooning, and no definition of the medium can be complete without embracing it".

Given the above, the development of systematic and multidimensional studies of diverse cartoons produced by cartoonists nowadays might shed light on these issues. We propose that a meaningful step in this direction is to establish a set of dimensions capable of grasping this diversity, based on the dialogue between empirical research and theoretical backgrounds. That will be our goal in this work, in which a wide variety of visual and multimodal contemporary cartoons will be analysed. We believe that such an effort can be conducive to a deeper understanding of this rich although often little considered genre. This is particularly relevant if - as stated by Forceville $(2002,2006)$ - genre is a crucial framing device governing interpretation.

This paper is structured as follows. Based on a concise review of relevant features that characterise a discursive genre, a description of the cartoon genre is provided, mainly regarding modal, thematic, rhetorical and pragmatic features. The structure of cartoons is proposed to arise from the co-occurrence of a referenced (or target) situation and a fictional situation. Next, the usage of 'political', 'editorial' and 'gag' cartoons is commented on. After the literature review, the rationale, aims, corpus and methods of the study are described. Phase 1 of analysis focuses on whether and how themes and pragmatic motivations serve to distinguish cartoons and more specifically, build the referenced situation. After identifying 
cartoon subgenres, Phase 2 aims at analysing whether and how they also differ according to their rhetorical resources, thus focusing on how the fictional situation is built. Results are informed and illustrated with cartoons that are typical of each group. Finally, the main findings of the study are discussed while suggestions for further research are outlined.

\section{Cartoons as a discursive genre}

According to Bakhtin (1986: 78), a discursive genre is composed of "relatively stable typical forms of construction of the whole" considering "thematic, compositional and stylistic" features (1986: 64). There is a continuum extending from stability to variation, so that some forms are rigid and standardised while others are "flexible, plastic and creative" (Bakhtin 1986: 78). Compagnon (2001) also refers to these dynamics when stating that generic rules should be understood as productive rather than as repressive, insofar as they can be transgressed and evolve.

Steimberg (1998) has reflected upon genres in the media and proposes three main levels to distinguish them: enunciative, thematic and rhetoric. In the field of cartoons, Schilperoord \& Maes (2009) and Forceville (2016) also mention pragmatic considerations when referring to how a cartoon is interpreted. Besides, since semiotic modes actively participate in the meaning - and humour-making process in cartoons, as put forth by the multimodal approach (Martinec \& Salway 2005; Kress \& van Leeuwen 2006; Tsakona 2009; Kress 2010; Jewitt 2011; Agüero Guerra 2013, 2016; Serafini 2013; Al Masri 2016), a modal level should also be considered.

The enunciative level considers the meaning effects by which a communicative situation is built, regarding the-sometimes implicit-relations between the "transmitter" and "receiver" of the text (enunciator and addressee in the original source; Verón 1992). The thematic level considers the situations presented by taking into consideration historically elaborated schemes that transcend the specific content of the text itself (Segre 1985; Steimberg 1998). The rhetoric level includes all of the mechanisms that shape the text (Steimberg 1998). Finally, the pragmatic level focuses on the interpersonal and community phenomena of communication, particularly on the use of language in communication as well as on the interpretations people give to messages in specific contexts (Zecchetto 2006). Let us now look at how these levels can be found in cartoons. ${ }^{1}$

Focusing on the modal level, drawing is an essential feature of cartoons, combining iconic and plastic signs (Groupe Mu 1992). Often, writing contributes to meaning through a range of devices (i.e. bubbles, titles, legends, captions, labels, placards and onomatopoeia) that unfold within the picture. Plastic features in the writing, such as colour, thickness, size and arrangement of letters are amalgamated in writing, frequently contributing to the construction of a given message (see Groupe $\mathrm{Mu}$ 1992; Saraceni 2003; Beguin-Verbrugge 2006; Kress 2010, among others). The fusion of verbal and visual modes makes cartoons genuine multimodal texts (Vilches 1984) in such a way that each mode ceases to be autonomous in creating meaning and, specifically, humour.

Turning now to the thematic level, the origins of cartoons are related to the pioneer work of William Hogarth (1697-1764), who satirised customs and mores from his time in England (Thivolet 1996). Monarchs and revolutionaries also became the target of cartoons in many satirical newspapers of European countries. In times of revolution in France, for instance, political caricatures gained such an influence in public opinion that they were considered by Boyer de Nîmes ${ }^{2}$ and other contemporaries as "the thermometer of opinion" (quoted by Duprat 2002: 13). During the 19th and early 20th centuries, cartoonists came to be regarded as influential and highly respected political commentators (Walker 1978; El Refaie 2009). 
Nowadays, cartoons touch on countless topics, such as current social, media or political events; endemic/structural problems such as hunger, social inequality or exile; customs and mores, including myths, social beliefs and practices and religious stories.

When we look at cartoons by combining thematic and rhetoric levels, two essential components of cartoons can be identified: the referenced situation and the fictional situation or, in short, play. The referenced or target situation is the topic of the cartoon. In order to belong to the genre of humour, a 'counter face' to the referenced situation is built in the text. This is the fictional situation set up by the author (El Refaie 2009; Pedrazzini \& Scheuer 2010). In Edwards' words, "cartoons act as a bridge between fact and fiction" (1997: 8). The reconstruction made by the cartoonist introduces an inconsistency, a breaking of expectations (Attardo 1994). In line with incongruity theories of humour, the basic mechanism of humour in cartoons comes from the association of at least two incompatible, namely incongruous, elements or ideas ("scripts" in the terms of Attardo \& Raskin 1991; Attardo 1994). Once the incongruity is perceived, a cognitive effort takes place in the form of problem solving (Suls 1972) in order to partially or totally resolve the incongruity (Attardo 1997; Attardo et al. 2002).

Cartoonists play with absurdity, ridicule and distortion and usually articulate a literal meaning and one or various latent meanings. For this sake, they may use a wide range of resources with varying skill and creativity. Some resources transcend the genre of humour, such as rhetorical figures. Among these, metaphor and metonymy have been largely considered and put forth as basic resources operating in cartoons (e.g. El Refaie 2003, 2009; Schilperoord \& Maes 2009; Bounegru \& Forceville 2011; Negro Alousque 2013, 2014). The ways in which irony and sarcasm introduce a gap between what is said and a different intended or underlying meaning (Kerbrat-Orecchioni 2013) has also been studied in cartoons (e.g. Groupe $\mathrm{Mu}$ 1978; Conradie et al. 2012). The particular value of these resources resides in simultaneously quoting an opinion and taking distance from it (El Refaie 2005).

Keeping in mind that cartoons are texts of high density in which several sources of humour co-occur (a feature called hyperdetermination of humour by Attardo 2001; see also Tsakona 2009), we sought to document the huge spectrum of rhetorical resources operating in cartoons. To this end, we have adapted (Pedrazzini \& Scheuer 2010, 2012 and forthcoming) the traditional division of four groups of rhetorical figures: speech, meaning, construction and thought (Beth \& Marpeau 2005; Fromilhague 2005). Namely, figures of contiguity, figures of association, figures of double meaning, figures of construction, irony and sarcasm, and other figures of thought. In addition, we have also identified certain resources that are more specific to humour, such as role reversal (Bergson 1911; Attardo et al. 2002), absurdity (Charaudeau 2006), irony of fate (Schoentjes 2001) and parody (Hutcheon 1985; Tillier 2005). Another group of resources relies on actualising cultural references (Pedrazzini 2011) that go beyond the referenced situation, involving wide semantic fields (arts, history, media, sports, etc.) upon which the humorous play is built. Parody and cultural references often function as intertextual procedures that call upon a collective memory with humorous and satirical ends (see Werner 2004; Tillier 2005; Houdebine-Gravaud 2013; Pedrazzini \& Scheuer 2017). Moreover, rhetorical resources are conveyed by means of varied semiotic modes, which are solely visual in the case of cartoons relying on drawing only, and also verbal and multimodal in the case of visuo-verbal cartoons.

Several pragmatic facets are also at play in cartoons. Among them, the cartoonist's motivation has an influence on his/her choices regarding any of the previously mentioned semiotic levels. The cartoonist's motivations may range from social commitment when denouncing and criticising one aspect of reality to playful entertainment (Tillier 2005) or selfreferential humour expressing aspects of the own identity. The cartoonist may seek to make the readership reflect upon a certain issue, provoke laughter or amusement or express 
him/herself. As mentioned above, from their very origin cartoons are narrowly linked to satire, whether it is focused on customs and mores or politics. A moral duty usually guides cartoonists towards what they believe is good (Duval \& Martinez 2000; Shelton Caswell 2004; Pedrazzini 2011).

\subsection{Scope of common terminological usages: Political, editorial and gag cartoons}

As stated above, literature review reveals that most studies within the field of cartoon genre tend to focus on one type of cartoon, disregarding others. Some studies approach political cartoons, others refer to editorial cartoons and a few to gag cartoons. Let us review how these types of cartoon are defined in the literature. El Refaie states that

political cartoon constitutes a very specific genre, with its own history, distinctive styles, conventions and communicative purposes. (...) What makes political cartoons unique is the way in which they typically use a fantasy scenario to comment upon an aspect of topical social, political, or cultural reality.

(El Refaie 2009: 182, 184)

This author further proposes that the connection between these two situations - in our terms, referenced and fictional- "is essentially metaphorical, inviting people to map properties from a more tangible area of reality onto one that is more abstract" (2009: 186, for a similar standpoint see also Templin 1999; Edwards 2001; Schilperoord \& Maes 2009).

Elaborating on El Refaie's (2009) proposal, Negro Alousque (2013: 370) lists five defining features of political cartoons: 1) they have a descriptive function related to the referenced situation addressed; 2) factual knowledge is essential in the interpretation process; 3) recent events are combined with an imaginary world and the connection between the referenced and fictional situations is conveyed predominantly by means of visual metaphors, 4) these cartoons present a critical perspective on the referenced situation addressed; and 5) they are essentially satirical: individuals are caricatured.

In the literature, political and editorial cartoons frequently appear as partially overlapping categories - a problem we intend to contribute to solving in this paper. Indeed, what some scholars consider as features characterising political cartoons are also attributed as defining features of editorial cartoons. To make matters more complicated, editorial cartoons are not necessarily published in the editorial page of a newspaper, nor do they always express the editors and publishers' opinion. Steuter \& Wills (2011: 324-325) posit that timely and topical editorial cartoons "are meant to elaborate and comment upon current events, and usually they articulate a specific political message from a particular ideological perspective (...) $[\mathrm{T}]$ hey are persuasive communications with the rhetorical force of editorials or op-ed columns".

It could be argued that in editorial cartoons, major emphasis is attributed to the author's personal perspective and consequently to the cartoon's argumentative, thus persuasive value, than what is regularly found in political cartoons. In editorial cartoons, authors express a high degree of commitment oriented towards a moral purpose: "to further the cause they passionately support or to thwart a perceived wrong" (Shelton Caswell 2004: 17). Along this line of thought, and considering that the intertwining of commitment and a tacit morality is a main trait of satire (Duval \& Martinez 2000), it could be put forth that editorial cartoons evidence a "satirical nature" (Negro Alousque 2013) in a larger extent that political cartoons do. In effect, the satirist denounces and criticises what $\mathrm{s} / \mathrm{he}$ considers as vices and flaws of a given person or group.

In contrast, gag cartoon appears as a clearly distinct type of cartoon. According to Harvey (2009), its beginnings go back to the times of William Hogarth (1697-1764), James 
Gillray (1756-1815) and other European contemporaries. By the nineteenth century, magazine cartooning had branched into "the political and the purely comic (the latter, eventually termed 'gag cartoons' by cartoonists)" (Harvey 2009: 28). In the 1920s, gag cartoons evolved into a more economical style, in which drawings and words blend to produce humour. The "single speaker captioned cartoon" appeared and became characteristic of The New Yorker style: "The picture sidles into a reader's consciousness as a kind of visual puzzle, meaningless until reading the caption 'explains' it. The picture like-wise 'explains' the caption" (Harvey 2009: 29).

While Harvey distinguishes gag cartoons based on their rhetoric, other scholars do so by addressing their themes, or at least one of their recurrent topics. According to Shultz \& Germeroth (1998), in gag cartoons, taboos are confronted openly (e.g. outrageous sexual situations, disabilities, or instances of death), which explains why such cartoons are called "sick humour".

Based on this brief characterisation of political, editorial and gag cartoons, we conclude that all of the core levels defining cartoons as a discursive genre-pragmatic, thematic, rhetoric and modal - should be considered in order to delineate intra-generic differences. Nevertheless, it seems to us that these levels play a different role in shaping types of cartoons, with thematic and pragmatic levels being the basis for rhetorical and modal choices. In addition, studies in the field often fall short in taking simultaneously and systematically into consideration certain questions allowing to delve into cartoons as "a plural object" (Tillier 2005: 10), that is, a heterogeneous discursive genre. For instance:

- Is commitment the only motivation for cartoonists in political cartoons?

- Considering that political matters have historically dominated the themes addressed in cartoons in press, can cartoons that do not address political issues play an "editorial" role? In such a case, what are those issues?

- Is metaphor the distinctive rhetorical resource in political cartoons? Are there any rhetorical resources specific to gag/playful cartoons?

- Do the semiotic modes have an influence on the cartoons types?

The above questions have guided our study directed at analysing the complexity of the cartoon discursive genre by articulating both a close-up and an integrated approach.

\section{Rationale and aims of the study}

The major aim of this study is to contribute to the conceptual delimitation of the cartoon genre from the standpoint of corpus-based qualitative, fine-grained research. The above literature review points at the suitability of taking into account four semiotic levels at play in cartoons: modal, thematic, pragmatic and rhetoric. We intend to investigate whether particular constellations of features at different levels emerge, allowing us to identify cartoon subgenres. Our first aim is to study whether subgenres can be identified by considering the situation addressed in the cartoon (referenced situation), specifically in terms of the cartoon's theme and motivation. Secondly, we explore whether such thematically and pragmatically defined subgenres exhibit particular rhetorical patterns. In this phase, the focus is set on how the fictional situation is built. In addition, we seek to analyse the modal contributions of drawing and writing in shaping both the referenced and the fictional situation.

We expect, firstly, that cartoon subgenres emerge from the consideration of the two aforementioned semiotic levels, namely the thematic and pragmatic ones. Secondly, we expect to find at least three different types of cartoons in our corpus: those addressing 
political issues from an editorial standpoint; those addressing issues other than political from an editorial perspective; and gag or playful (a wider embracing term) cartoons.

\section{Methodology}

\subsection{Procedure and corpus}

Differently than what is usual in corpus-based research, in this study we sought to obtain a corpus of cartoons endorsed by the cartoonists themselves. In the context of a comprehensive questionnaire which explored the cartoonist's professional background, manner of working, view of cartoons as a genre, and view of his/her own work, each participant was asked to choose a piece of his/her own work that was representative of his/her own style. No further specifications were provided so as to enable cartoonists to operate according to their own criteria, which they were asked to explain. We assume - and some of the cartoonists made it explicit - that a positive assessment of such works played a role in the choice made.

The resulting corpus consists of 85 single-panel cartoons, 51 of which are multimodal and 34 are solely visual. The reasons given by the cartoonists for their choice included the four aforementioned levels: pragmatic (commitment, playfulness, expression of their own identity in terms of cultural origins or genre, positive reception among readers), thematic (being fond of or concerned about particular issues), and rhetoric and modal (a particular way of using visual/verbal resources). The questionnaire was distributed via e-mail individually or through organisations of cartoonists, including the Federation of Cartoonists (FECO), Le Salon International de la Caricature, du Dessin de Presse et d' Humour (France), and the Cartoon Movement, in French, Spanish and English. The questionnaire was completed by 92 cartoonists. Among them, the contributors to the corpus were 79 cartoonists $^{3}$ from 21 countries in five continents (54 per cent from Europe, 30 per cent from Latin America, 10 per cent from North America, 3 per cent from Asia, and 3 per cent from Africa).

\subsection{Analysis}

We analysed cartoons by extending a system of categories that took into account the theoretical background and empirical findings reviewed above. In agreement with our aims, the dimensions and categories considered in this study refer to modal, thematic, pragmatic motivation and rhetoric levels. The dimensions and their corresponding categories are the following:

Modal level. The modal level intervenes in shaping both the referenced and the fictional situations in the cartoon.

- Solely visual, multimodal.

Thematic level. The referenced situation is coded according to two thematic sub-dimensions: Object and Occurrence. Object seeks to capture the sphere and duration of human activity addressed in the cartoon. Occurrence informs whether and eventually when this activity actually occurs.

- Object: political event; endemic or structural political problem; media, arts and sports events; customs and mores.

- Occurrence: mythical/fictional, present time, timeless.

It is important to clarify that even if all productions are conditioned by time, the category timeless is applied to situations that can last decades or even centuries. Not a single cartoon addressed events that occurred in the past and are no longer happening nowadays. 
Pragmatic level. The analysis of this level is restricted to inferring the cartoonist's motivation regarding the social function played by his/her cartoon.

- Commitment, playfulness, mixed motivation.

We began by considering a category of self-referential humour by which the cartoonist expresses aspects of his/her own identity. However, the category was dropped because of its low presence in the corpus and mostly because all of these cartoons also evidenced one of the three motivational categories considered.

Rhetorical level. The fictional situation is coded according to two dimensions: Type of resource and Density.

- Type of rhetorical resources (this is the only dimension for which categories are not mutually exclusive): figures of contiguity, figures of association, figures of double meaning, figures of construction, irony and sarcasm, other figures of thought, specific humorous resources, cultural references (see Table 1). For each of these eight groups of resources, we coded whether none or at least one among such resources was at play in the cartoon (i.e. absence vs. presence). As a result, Type of rhetorical resources was composed of 16 categories.

In a same cartoon different types of resources frequently coexist. This is the reason why it is worth considering the rhetorical density of cartoons.

- Rhetorical density: 2-4 resources per cartoon, 5-7 resources per cartoon, 8-12 resources per cartoon.

The numbers express the total number of resources that were identified in each cartoon, whether they belonged to different or to the same type.

Table 1. The eight groups of resources considered in the analysis of the Rhetorical level.

\begin{tabular}{|l|l|l|}
\hline \multicolumn{2}{|l|}{ GROUPS OF RHETORICAL RESOURCES } & SPECIFIC RESOURCES \\
\hline \multirow{2}{*}{ Figures of meaning } & Figures of contiguity & Metonymy, synecdoche. \\
\cline { 2 - 3 } & Figures of association & Metaphor, oxymoron, symbol. \\
\cline { 2 - 3 } & $\begin{array}{l}\text { Figures of double } \\
\text { meaning }\end{array}$ & $\begin{array}{l}\text { Calembour, syllepsis, play on words, among } \\
\text { others. }\end{array}$ \\
\hline Figures of construction & $\begin{array}{l}\text { Antithesis, parallelism, ellipsis, repetition, } \\
\text { inversion, gradation, among others. }\end{array}$ \\
\hline \multirow{2}{*}{ Figures of thought } & Irony and sarcasm & Irony, antiphrasis, sarcasm. \\
\cline { 2 - 3 } & Other figures of thought & $\begin{array}{l}\text { Hyperbole, litotes, allusion, paradox, } \\
\text { substitution, among others. }\end{array}$ \\
\hline Specific humorous resources & Absurdity, parody, role reversal, irony of fate. \\
\hline Cultural references & \\
\hline
\end{tabular}


Overall, analysis involved a grounded theory approach (Strauss \& Corbin 1998) in which data were coded at the same time as we were adjusting available categories or developing new ones, in an iterative process that continued until the data no longer changed the categories being developed. Category analysis was based on repeatedly reading the cartoons. In addition, specifically regarding the cartoonist's motivation (pragmatic dimension) and the referenced situation addressed (thematic dimension), a post hoc triangulation procedure (Denzin \& Lincoln 2005; Lockyer 2006) was applied: the cartoonist's explanation for having chosen that particular cartoon as representative of his/her style was considered in order to resolve ambiguities, uncertainties or lack of information. For instance, our coding of Biratan's cartoon (see Figure 7) as responding to a playful motivation was supported by the explanation he provided in the questionnaire: 'I'm essentially a humorous cartoonist. I enjoy making cartoons. To make people laugh, to make people, readers, happy. This one in particular was very appreciated. 'The neighbours'. I think it is a relationship with endless inspiring situations for a humorous cartoonist". An example of an explanation that was useful to identify the referenced situation addressed was Savignac's (see Figure 2 and Appendix): "The massacre of Tian'anmen in China in 1989".

Researchers coded all the cartoons independently, after which results were compared. When the results did not match, the discrepancy was resolved through negotiation. Next, two techniques from multivariate descriptive statistics were applied in order to capture the associations among dimensions of analysis: Multiple Correspondence Analysis (Greenacre 1984) and Hierarchical Ascendant Classification (Ward 1963), using the SPAD 5.5 software. These techniques have fruitfully been applied to corpus of cartoons (for instance, Pedrazzini 2011, Pedrazzini \& Scheuer 2010, 2012, 2017). Multiple Correspondence Analysis (MCA) is a tool to study a group of individuals (in this case the 85 cartoons) described by a set of qualitative variables formed by mutually exclusive categories. MCA enables visualisation of associations among categories and individuals on a set of factorial axes. All categories and individuals are projected on the factorial plane. Groups of categories and individuals can be formed with those that have achieved a good statistical representation $(\geq 2)$ and are close in the factorial plane.

In the Spad context, Hierarchical Ascendant Classification (HAC) classifies individuals according to their coordinates on the main factorial axes provided by the MCA. HAC is especially useful when a large number of factorial axes is to be considered, in order to ensure the quality of the statistical representation of categories and individuals. This technique begins by looking at the population of participants so that each one is the only element in a class. At each successive iteration, the two classes which are least distant (according to Ward's similarity index) are grouped into a new class, until a single class encompasses all the individuals. This iterative process is represented in a tree-structured graph called dendrogram. For each class of individuals, HAC informs over- and under-represented categories and arranges all the individuals in order according to their typicality, allowing representative examples to be selected.

We analysed the relations among the four levels presented above in two phases. The purpose of Phase 1 was to analyse whether the 85 cartoons differed according to their themes and pragmatic motivations. Phase 2 aimed at analysing whether the different groups of cartoons distinguished in Phase 1 also differed according to the number and type of rhetorical resources. Whereas Phase 1 focused on the construction of the referenced situation, Phase 2 analysed how the fictional situation is set to address the referenced situation. 


\section{Results}

\subsection{Phase 1: Cartoon subgenres defined by themes and pragmatic motivations}

In order to analyse whether it is possible to distinguish cartoons according to thematic and pragmatic levels, we conducted a MCA considering the following dimensions: Object of Referenced situation, its Occurrence and Cartoonist's motivation. The modal level was considered in order to explore its eventual relations to the thematic and/or pragmatic levels. We identified three main groups of cartoons based on the following categories (see Figure 1):

Group 1, formed by: political event, present time, mixed motivation, commitment. Due to the content of this constellation of categories, we named this group as Daily political cartoons.

Group 2, composed of: political structural situation, timeless, commitment. Hence, this group was termed Timeless political cartoons.

Group 3, formed by: customs and mores, mythical/fictional time, playfulness. This constellation was synthesised as Playful cartoons.

The Object category "Media, arts and sports events" achieves a good statistical representation in axis 3 and is associated with the present time. These cartoons could be considered a subgroup of the Daily cartoons.

The fact that both Modal categories are located close to the centre of the factorial plane indicates that they do not present any significant association with other categories. This means that in this corpus of cartoons, modal choice was not found to be associated with the thematic or pragmatic aspects analysed.

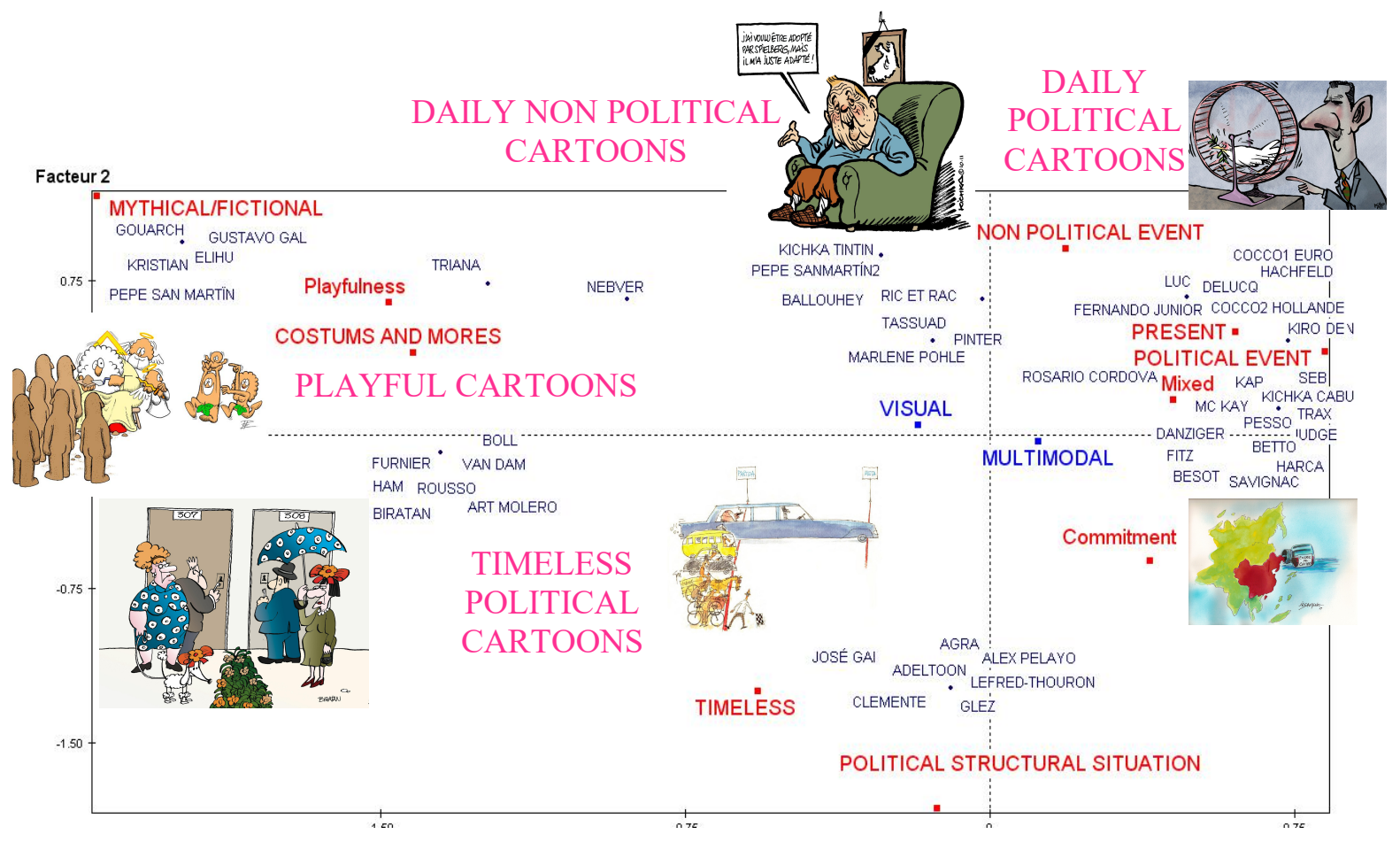

Figure 1. Cartoon subgenres identified and their corresponding examples are projected in the factorial plane formed by axes 1 and 2 obtained from MCA. Cartoons reprinted with cartoonists' permission. 
In the next paragraphs we will illustrate each subgenre by means of examples from our corpus (Figures 2 to 7). Readers may also find the cartoonists' corresponding justifications in the Appendix. Let us note that the analysis of the relationships among the content of the cartoonists' justifications and the semiotic features identified in the cartoons lies beyond the scope of the present work.

Daily political cartoons can be characterised by two different motivations: commitment and a motivation that combines commitment and playfulness. An example of the first case is Savignac's cartoon (Figure 2), which as mentioned above, alludes to the massacre of Tian'anmen that occurred in People's Republic of China in 1989 (the cartoon was produced the same year). The rhetorical resources used by the cartoonist to address this event provoke impact and show a strong commitment. Figure 3 refers to the Syrian president Bashar alAssad's violent politics. Even if commitment can be inferred on the part of the cartoonist since he addresses a serious issue and denounces a particular standpoint - the cartoon also seeks to amuse, since it may be funny to see the pigeon of peace caricatured with a comic expression in the place of a hamster.

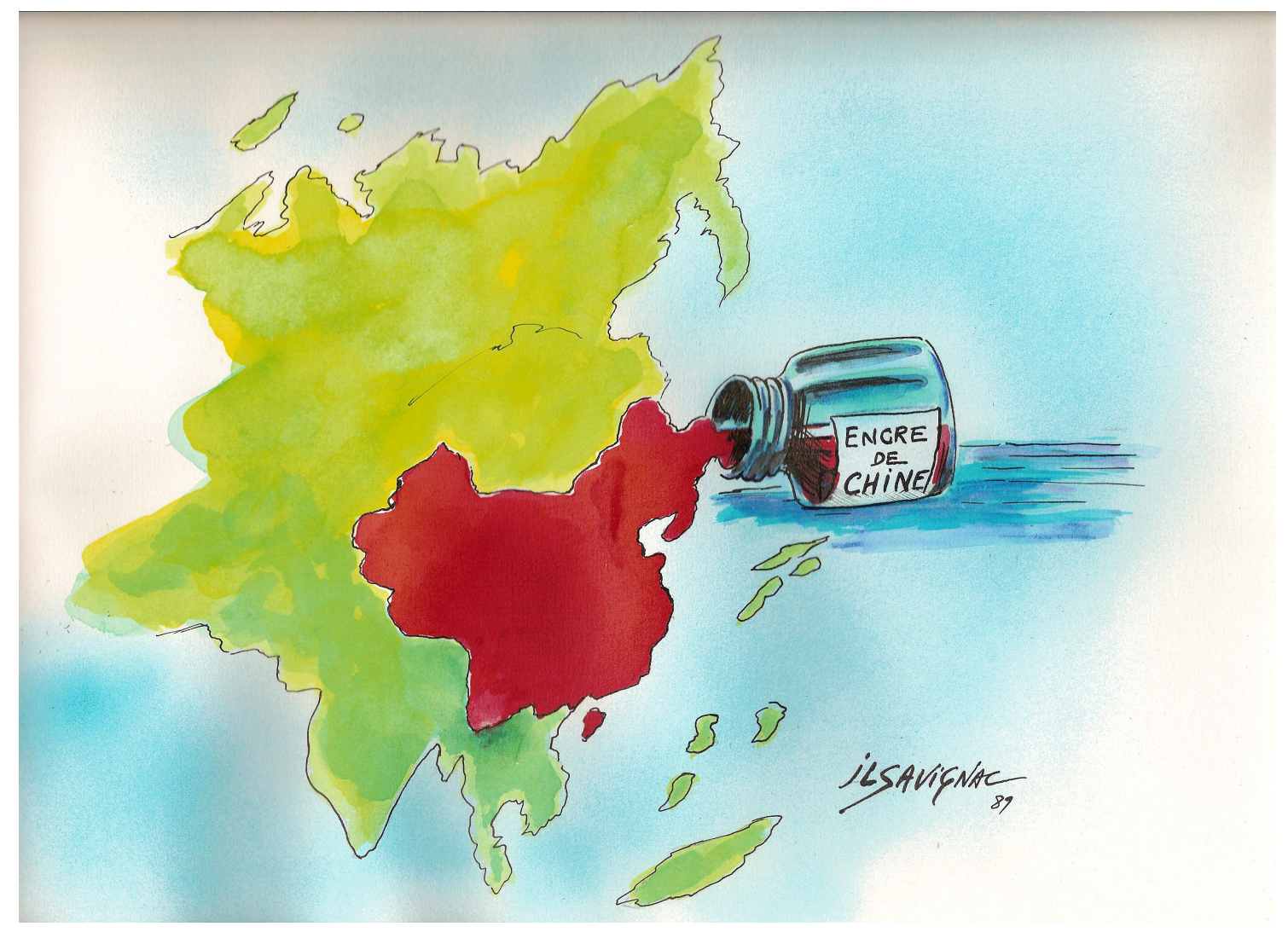

Figure 2. Savignac, France. 


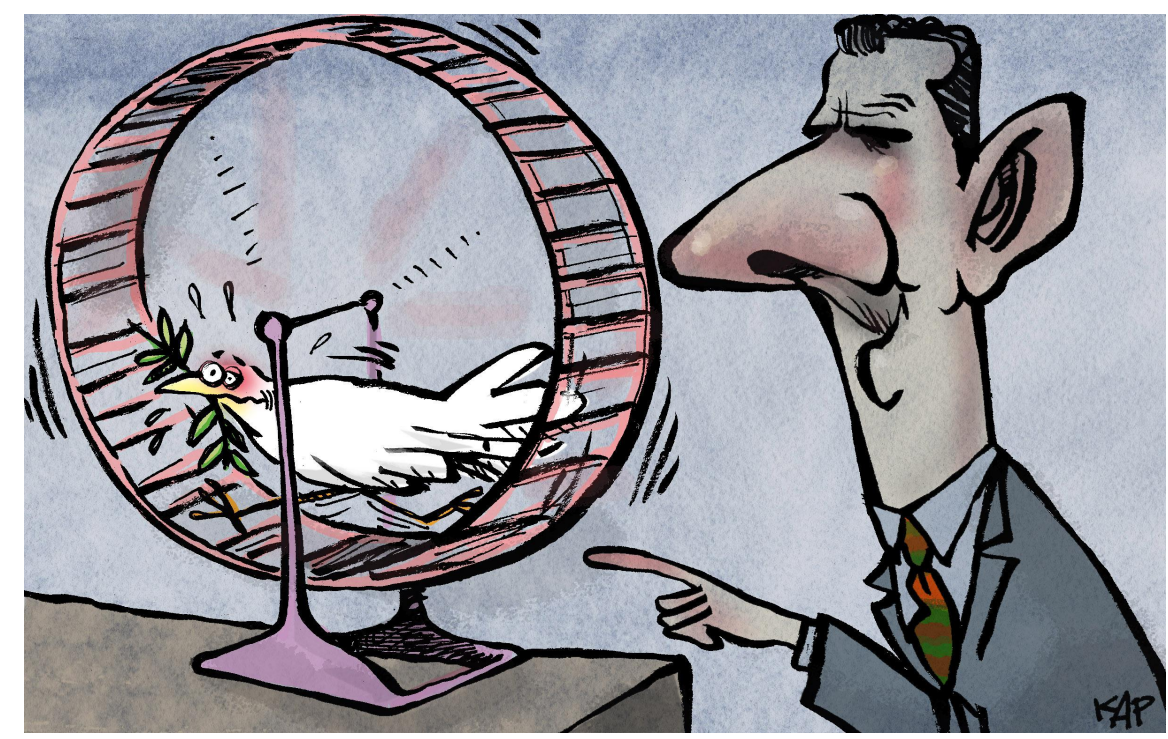

Figure 3. Kap, Spain.

One example of Daily media, arts and sports cartoons is Kichka's piece about the remake on 3D of Tintin, the classic story of the Belgian character of comics (see Figure 4). In the image we can see an old Tintin saying: "I wanted to be adopted by Spielberg but he just adapted me!". The cartoonist is playing with the words adopt and adapt, alluding both to Tintin being an orphan and to Spielberg's remake. Let us note that Milou's picture hangs on the wall with a black ribbon placed on it, meaning that Milou is dead. The dog's death and the old appearance of Tintin point out that the first comic was published a long time ago (in 1929).

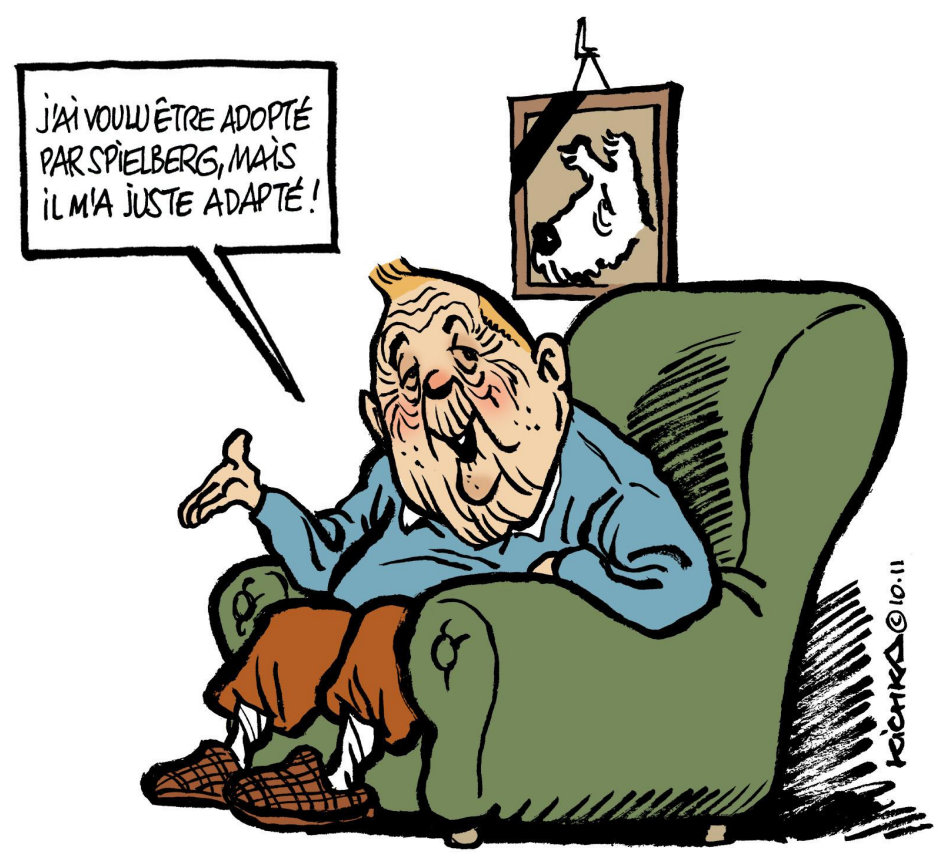

Figure 4. Kichka, Israel. 
Timeless Political cartoons address endemic situations such as hunger or social inequalityas is the case in Figure 5. Because of the permanence of the objects addressed, these cartoons could be published at any time. In some cases, they appear in reference to a current issue, thus acquiring a status similar to stock photos usually published in the press. Due to the topics addressed, we may assume that commitment is the cartoonist's main motivation when producing these cartoons. They seek to present an opinion, criticise, denounce, provoke reflection. On the contrary, in Playful cartoons - as stated by their name - cartoonists seek to provoke laughter. Customs and mores are the most usual topic here, framed either in a mythical or fictional time, as is the case in Figure 6, which addresses the story of Adam and Eve, or in a timeless situation, as in Figure 7. Biratan's cartoon presents a funny look at a daily life situation in the consumer society in which two neighbour couples are depicted entering their homes.

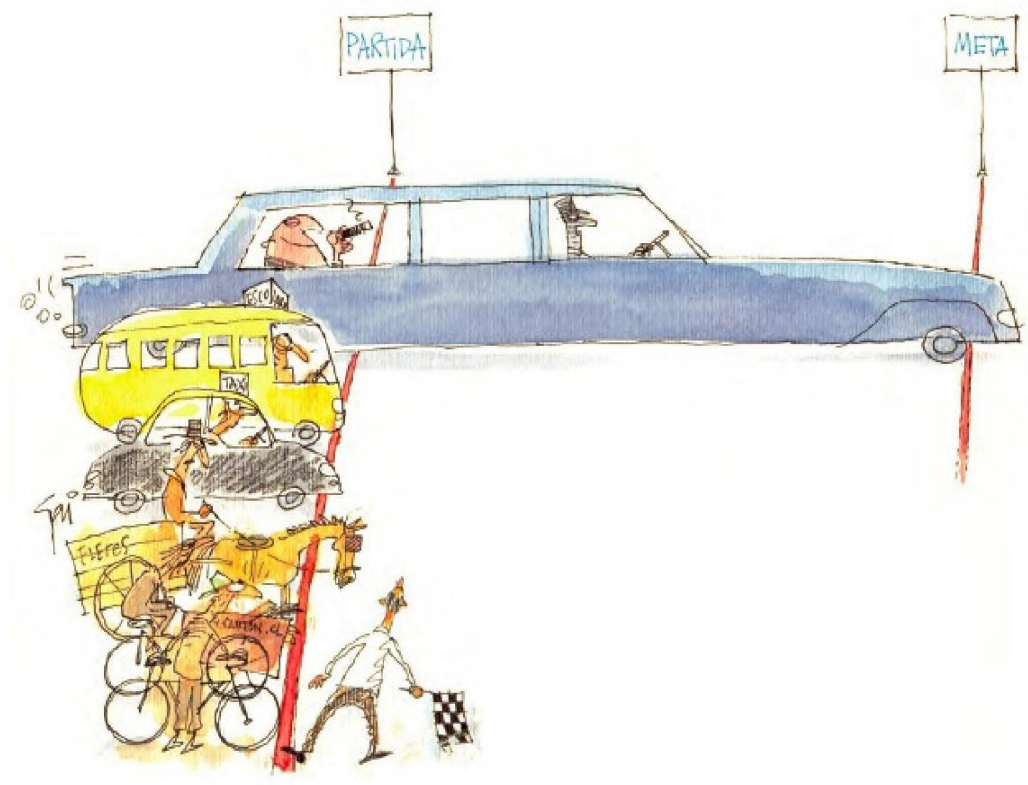

Figure 5. José Gai, Chile.
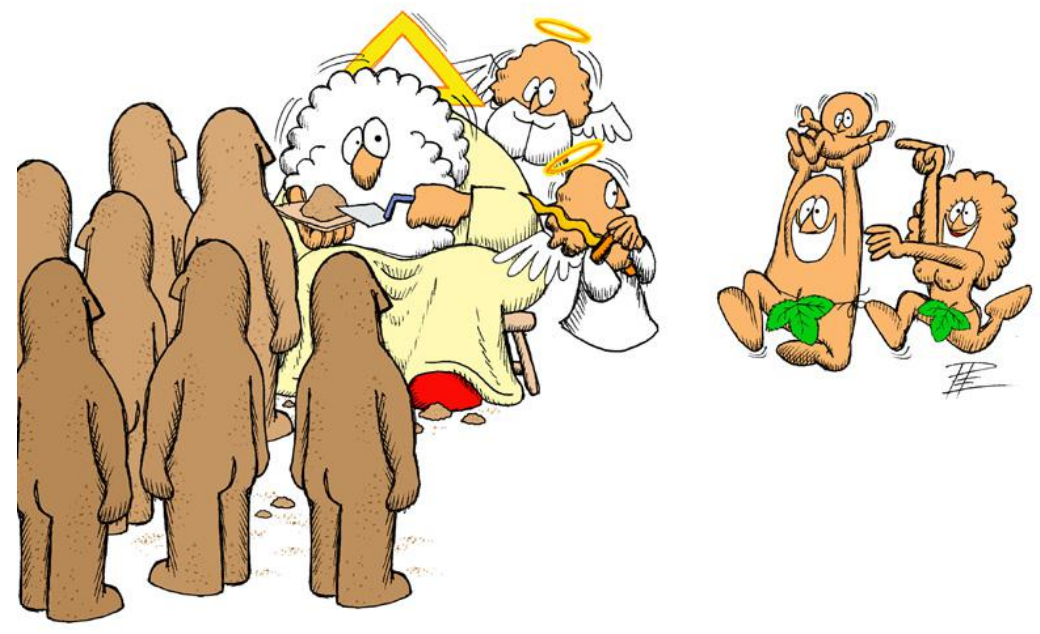

Figure 6. Pepe San Martín, Peru. 


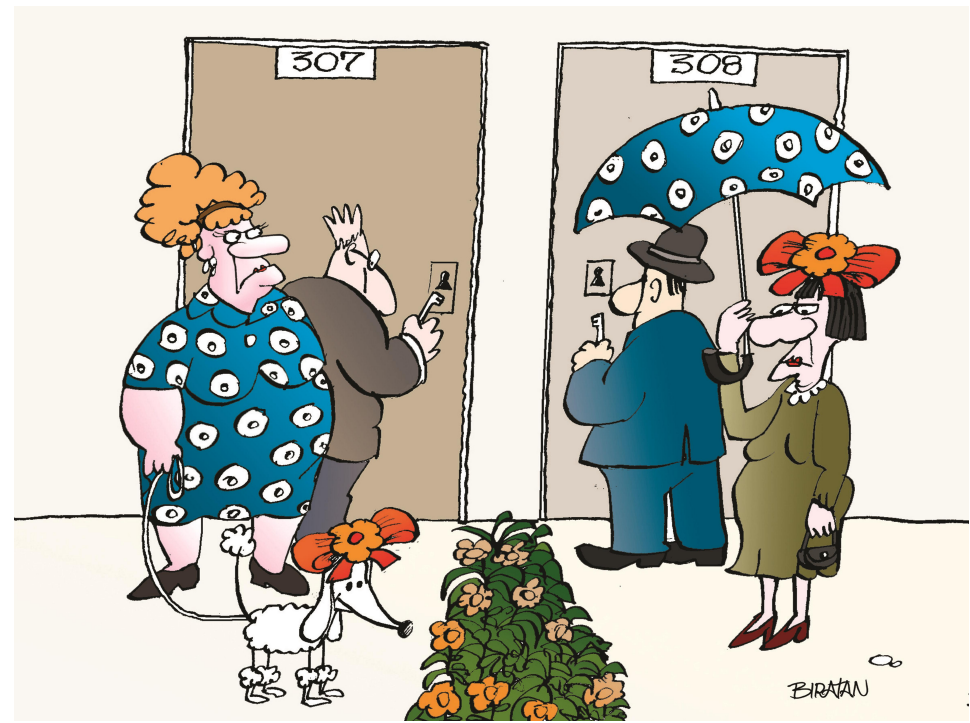

Figure 7. Biratan, Brazil.

Having identified four cartoon subgenres by their themes and in three of them also by the cartoonists' motivations, we calculated their distribution in our corpus. As shown in Figure 8, they are unevenly distributed, in such a way that Daily political cartoons account for almost half of the corpus, while, at the other end, Daily media, arts and sports cartoons are less than 10 per cent.

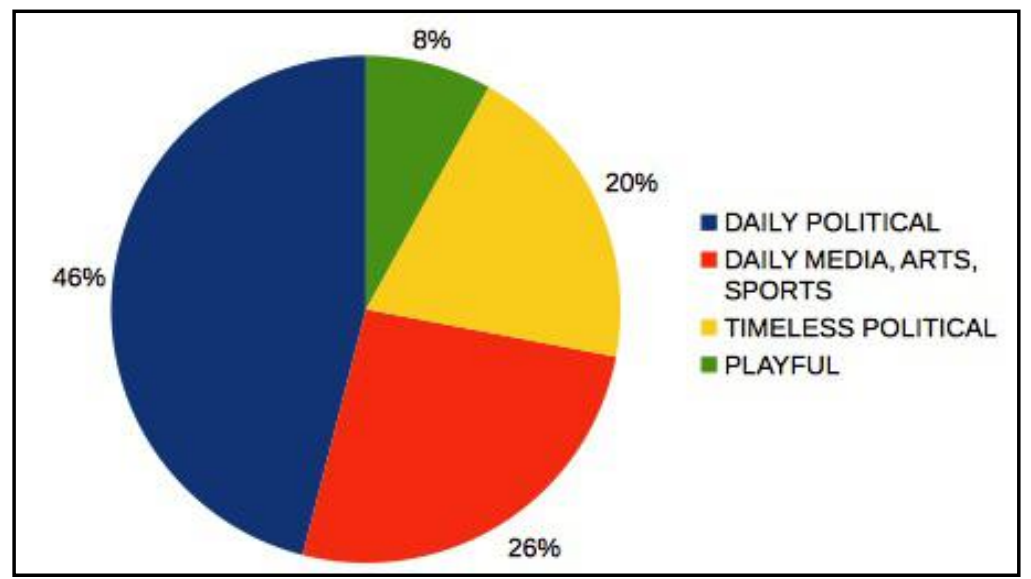

Figure 8. Distribution of the four cartoon subgenres from our corpus.

\subsection{Phase 2: Cartoon subgenres and their rhetoric}

The next step was to study if the four subgenres present distinct rhetorical patterns. With that aim, we conducted an MCA and subsequent HAC. The variables were the four cartoon subgenres, Type of rhetorical resources, Rhetorical density and Mode. The HAC was based on the first ten factorial axes of the MCA, which explained 92 per cent of the total variability of the data analysed. The results provided by the HAC allowed us to identify four classes of cartoons, each corresponding to one of the four subgenres aforementioned (see Figure 9). The statistically significant categories are the following: 
Class 1: Timeless political cartoons, 8-12 resources per cartoon, figures of contiguity, irony and sarcasm.

Class 2: Daily political cartoons, 5-7 resources per cartoon, figures of association, figures of thought, absence of figures of construction.

Class 3: Playful cartoons, 2-4 resources per cartoon, absence of figures of association, absence of figures of thought, absence of irony and sarcasm.

Class 4: Daily media, arts and sports cartoons.

Classes 1 and 2 are closer to Multimodality in the factorial plane and classes 3 and 4 to the visual mode.

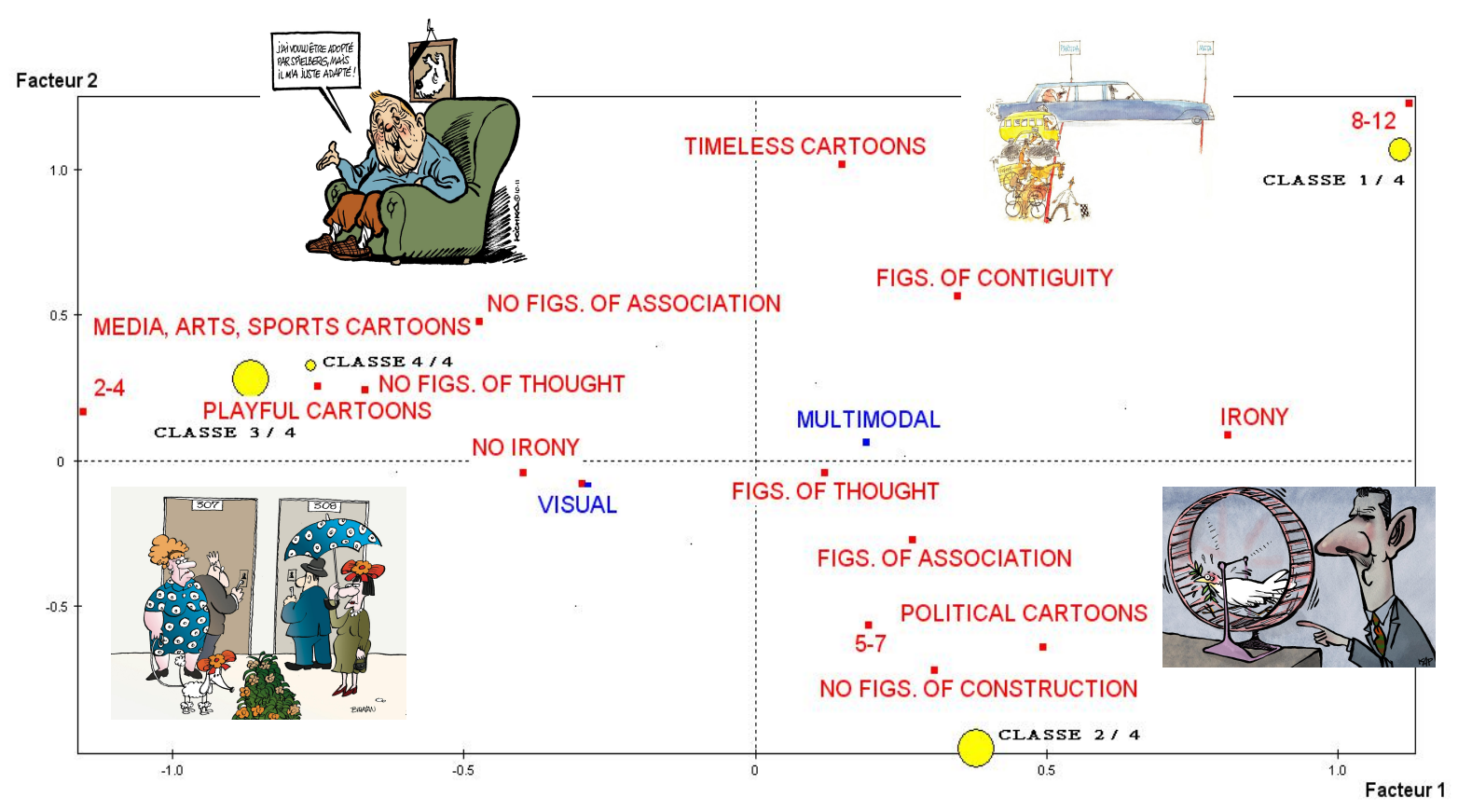

Figure 9. The four classes obtained applying HAC are projected in the first factorial plane.

Only those categories that present good statistical representation are projected.

Timeless political cartoons are the most rhetorically dense subgenre since they tend to present 8-12 resources per cartoon. Among these, figures of contiguity and irony and sarcasm are the most salient resources. In Figure 5, Gai refers to the everlasting issue of social inequality by means of the metaphor of a cars race. Each character stands for the group of persons (synecdoche) belonging to a social group, represented metonymically by their-in some cases caricature-like - means of transportation and clothes. The gradation of vehicles, from the most expensive to the cheapest one becomes an antithesis that opposes the powerful man on the top and the oppressed one on the bottom (see on this matter Kress \& van Leeuwen 2006; Pedrazzini \& Scheuer forthcoming). The cars race introduces a sarcastic point of view. Gai takes a critical distance to denounce the hypocrisy of the privileged onesmetonymically represented by a business man wearing a suit and smoking a cigar-towards the rest of the society. The marshal's naivety — checking that nobody crosses the start line-is absurd and hence funny, and contributes to build the farce.

Daily political cartoons present an intermediate rhetorical density, with an average of 5-7 rhetorical resources, in particular figures of association and figures of thought. A close look at the data allowed us to notice that 77 per cent of cartoons in this subgenre present at least one figure of association, consisting mostly in metaphor and secondly in symbol. The case of 
figures of thought is even stronger; at least one of these figures is deployed in 87 per cent of daily political cartoons (allusion and hyperbole above all). On the other hand, the absence of figures of construction is characteristic of this subgenre. In Figure 3, Kap builds up the metaphor of the pigeon of peace (a transcultural symbol) running exhausted on a hamster wheel and being manipulated by the President of Syria, Bashar al-Assad. The fact of manipulating the hamster wheel could be interpreted as a second metaphor of managing the world at his own will and for his own pleasure. The pigeon depicted as worn out in an iterative action that it could in fact avoid by simply flying away may activate a third metaphor for the seemingly not conducive actions of the ONU. In this sense, the wheel can be interpreted as a metaphor of the global implications of this seemingly deadlocked situation. The cartoonist alludes to the fact that the attempts to maintain peace in Syria are not working at all, and also denounces sarcastically Bashar al-Assad's intentions to appear as a nonviolent leader.

Playful cartoons present the lowest semiotic density, with an average of 2-4 rhetorical resources. These cartoons are characterised by the absence of figures of association and thought, and also by the absence of irony and sarcasm. A cartoon from this class is Biratan's one (see Figure 7), in which the setting is built on a symmetrical situation. Humour emerges from the antithesis based on finding the same object (a bow) and tissue (in the dress and umbrella) in different characters, and also based on the women's expression.

Lastly, Daily media, arts and sports cartoons do not present any specific rhetorical trend.

\section{Discussion and conclusions}

Our literature review reveals the lack of empirical and theoretical work dedicated to systematically grasping the diversity of cartoons. Taking genre discursive studies as a starting point, this paper aimed at analysing the cartoon genre and its subgenres, considering their modal, thematic, pragmatic and rhetorical features. The first phase of analysis focused on the construction of the Referenced situation and the second phase analysed how the Fictional situation was built and if different patterns emerged according to subgenre.

The combination of both qualitative analysis and statistical descriptive techniques proved to be useful for our purpose. As a result, four different groups of cartoons were distinguished: Daily political; Timeless political; Daily media, arts and sports; and Playful cartoons. Besides, the four semiotic levels considered in the study presented a different behaviour depending on the features of each cartoon. The thematic level served to characterise the four groups of cartoons. The pragmatic and rhetoric levels served to distinguish three groups. Lastly, the modal level differentiated cartoons in two main groups only in relation to rhetorical features.

Considering these results and recalling our two main hypotheses as listed in section 3 , we can conclude that, as expected, cartoon subgenres did emerge from at least two semiotic levels. However, even if the thematic and pragmatic levels served to define three of the subgenres, a clear contribution of the latter could not be identified in Daily media, arts and sports cartoons. Our findings support the second hypothesis only partially. Even if at least three different types of cartoons were identified in our corpus, our results show a higher degree of internal complexity than hypothesised. On the one hand, political cartoons not only adopt an editorial standpoint, they can also blend in commitment and playfulness. On the other hand, cartoons addressing current events (daily cartoons) are not indeed necessarily political, but we are not in a position to affirm that they are defined by an editorial standpoint. In what follows, the features corresponding to the four cartoon subgenres will be discussed and, whenever possible, relations with previous studies will be drawn. 
Political cartoons, which constituted the most frequent choice among cartoonists, conform to two subgenres: Daily and Timeless political cartoons. From a thematic level, they differ in the fact that whereas the first subgenre addresses current issues, the second one deals with endemic problems so that even if these topics appear nowadays, they go back decades and even centuries. In this sense, this specific subgenre can function as archive images which can be published at any time and have thus a longer life than Daily cartoons, whose correct interpretation requires updated factual knowledge on the part of the reader (Negro Alousque 2013). From a pragmatic level, Daily and Timeless political cartoons share commitment as their main motivation. A group of Daily political cartoons is also characterised by a mixture of commitment and playfulness. In such cases, the cartoonist's goal is not only to denounce a given issue and make the readership reflect, but also to amuse. This characterisation helps us to distinguish among cartoons such as Savignac's (Figure 2) and Kap's (Figure 3). Even if both address current violent events (in the time each cartoon was published), we could say that Savignac's motivation is to provoke impact whereas Kap proposes a funny look at a serious matter (see his explanation in Appendix), taking an affective distance (humour in stricto sensu; see Freud 1928, Pedrazzini 2011, Steimberg 2013).

The rhetoric level differentiates Daily and Timeless political cartoons in regard to both density and diversity. A possible explanation for the highest density identified in Timeless political cartoons is that, since they deal with recurrent topics which have been largely covered in the press, cartoonists may devote a special effort to capture interest by means of a greater amount of resources. A close look at this group of cartoons shows us that cartoonists often turn to visual stereotypes, "the visual shorthand understood by their readers" according to Shelton Caswell (2004: 20), since they make it possible to activate specific meanings in a compact and economical way. To that aim, metonymy and synecdoche appear as useful devices because of their ability to represent a whole group - as seen for instance in Gai's cartoon, Figure 5-by means of only a few signs. This partially explains why these rhetorical figures are characteristic of this subgenre. The importance of stereotypes in political cartoons and their relation to metonymy and synecdoche has already been highlighted by some scholars (Curti 2006; Bounegru \& Forceville 2011).

The other group of resources that characterise Timeless political cartoons are irony and sarcasm. These two rhetorical figures - very frequent in Daily political cartoons tooactivate a double discursive movement by which the ironist seems to support an opinion (sometimes widely spread), and at the same time s/he implicitly distances him/herself from it in order to question it. This mechanism - which can constitute a subversive strategy (El Refaie 2005) - is particularly suitable in Timeless Political cartoons since a different viewpoint about endemic situations can implicitly be suggested. Let us think, for instance, of usual prejudiced arguments and racist metaphors that are called into question.

In the case of Daily political cartoons, our results are in line with those of many scholars who claim that the link between the referenced and fictional situations in political cartoons is achieved by means of metaphors (see El Refaie 2003, 2009; Shelton Caswell 2004; Steuter \& Wills 2011; Negro Alousque 2013, 2014, among others). Referenced situations usually involve abstract concepts and metaphor is very conducive to represent such concepts in a more familiar way. A close look at the metaphors identified in our corpus shows that the visual mode - as claimed by some authors - is very propitious for metaphor deployment: for example, a president is portrayed as Jesus or a veterinarian, an economic crisis is represented as a storm (a recurrent conceptual metaphor identified by Bounegru \& Forceville 2011) or as a cardiac rhythm leading to death. In some cases, visual metaphors are reinforced by the verbal mode which facilitates interpretation.

Symbols and figures of thought, such as allusion and hyperbole, are other privileged tools in Daily political cartoons. These results match those provided by other studies of 
political cartoons, where metaphors, allusions, irony, sarcasm and hyperbole were found to be frequent resources (Pedrazzini \& Scheuer 2012). The importance of symbols can be due to their ability to synthetically stand for concepts, beliefs or ideologies, often abstract, such as peace, Judaism or a specific nation by means of a (visual) sign. Allusion allows cartoonists to address a topic obliquely, often the referenced situation, proposing a challenge for the reader to understand what the cartoon is about (Figure 2 is a good example of this). In doing so, cartoonists may rely on the fact that readers are already aware of current news so they can go beyond them resorting to figurative and implicit meanings. Hyperbole functions in an opposite way to allusion since instead of playing with implicit meanings, it exaggerates a situation or a celebrity's personal features with a satirical effect (Tillier 2005; Bounegru \& Forceville 2011).

Cartoons dealing with current media, arts and sports events may be considered a subgroup of Daily cartoons. The analyses carried out do not allow us to identify any specific pragmatic or rhetorical functioning. A close look at these cartoons shows a remarkable heterogeneity, considering both rhetorical density and types of rhetorical resources deployed. The lower semiotic definition of this group makes it more difficult to consider it a proper subgenre. A larger corpus would allow us to find out if this pattern remains, or whether a specific semiotic functioning emerges.

Concerning Playful cartoons, let us firstly note that we have preferred the term 'playful' to 'gag' because it seems to embrace a wider diversity of cartoons than the ones described as gag cartoons by the scholars reviewed in a previous section of this paper. Playful cartoons deal mostly with customs and mores that involve daily life situations, features of the human condition, myths, social beliefs and religious stories. This diversity explains two different performances concerning Occurrence: Playful cartoons can be considered timeless when they refer to situations that have existed for a long time, or the occurrence can be considered as mythical/fictional when the referenced situation is not actually happening. This is the subgenre with the lowest rhetorical density, which is why these cartoons present less of a cognitive challenge for the interpretation of the meanings deployed. This low density could be the consequence of the cartoonists' playful motivation. Their intention to provoke laughter might be hindered by dense and thus more complex cartoons.

The modal dimension did not vary according to the theme and pragmatic motivations of cartoons. It did vary, however, regarding their rhetoric. Daily and Timeless political cartoons are closer to Multimodality in the factorial plane, while Daily media, arts and sports and Playful cartoons are closer to the visual mode. This means that political cartoons rely more on the verbal mode to build their messages. This may be related to the need to minimally contextualise the referenced situation addressed. Accomplishing this might be easier by means of words and their interaction with the visual mode than solely visually. Along this line, many cartoonists posit that it is more difficult to produce political cartoons using only visual signs. $^{4}$

To sum up, the findings of our study allow us to answer our guiding questions - as formulated in Rationale and aims - in the following ways. Firstly, in the particular corpus that has been analysed it can be concluded that, although commitment is the cartoonists' key motivation in numerous political cartoons, there are cases in which political issues are motivated by the blending of commitment and playfulness.

Secondly, our analyses allowed us to identify daily cartoons that address other topics than political (media, art and sports events), but these are very scarce. Zooming into the cartoonists' motivations, commitment only appears in 14 per cent of those cartoons. Most frequent motivations when dealing with these topics are playfulness and its combination with commitment. 
Thirdly, metaphor is indeed a distinctive rhetorical resource in political cartoons notwithstanding the fact that other resources also play a significant role. Among them, the most notorious are irony and sarcasm, allusion and hyperbole. Along this line, it has to be noted that figures of association and thought (including irony and sarcasm) tend to operate with other rhetorical resources and, in particular, they often function in interaction. In addition, in some cases figures of thought are subordinated to metaphors in the meaning- and humour-making process. In-depth studies about how different rhetorical resources cooperate are scarce. Some contributions are focused on the interaction between metaphor and metonymy (Goossens 1990; Ruiz de Mendoza Ibáñez \& Mairal Usón 2007; Negro Alousque 2013; Ying-Yu Lin \& Chiang 2015) and some others offer a general panorama (Pedrazzini \& Scheuer 2012). In this particular research about political cartoons, we observed an association between irony and sarcasm and other figures of thought such as allusion operating in the verbal mode. This combination increases cognitive efforts in order to interpret implicit and indirect meanings since the reader not only has to reconstruct extra-textual references but $\mathrm{s} / \mathrm{he}$ also has to realise that what is said has to be understood in an opposite or different way.

Regarding the rhetoric of playful cartoons, not a single specific resource emerges as distinctive although two characteristic traits are the absence of figures of association and thought (including irony and sarcasm). Further work needs to be done to shed new light on this issue.

Lastly, our results show that modality has a partial influence on the definition of cartoon subgenres, regarding the rhetoric level only. In this sense, the relation between these two levels appears as a promising issue to further develop. Some efforts from other scholars have been made in relation mainly to visual and multimodal metaphor and metonymy (e.g. El Refaie 2003, 2009; Forceville 2006, 2016; Forceville \& Urios Aparisi 2009; Yus 2009; Negro Alousque 2013, 2014; Ying-Yu Lin \& Chiang 2015) and also from ourselves, maintaining interest in the whole range of rhetorical resources (see Pedrazzini \& Scheuer forthcoming).

Some other future lines of research are to explore how to implement the analysis of the enunciative level and study its potential to distinguish cartoon subgenres and also to include the potential effects of cartoons on the reader at a pragmatic level considering their impact or appeal to emotions. Finally, the application of this classification of cartoon subgenres to a larger corpus arises as an important step to follow in order to evaluate if the semiotic trends identified remain. It can also be informative to study how cartoon subgenres are distributed in different type of press, either from a historical perspective or focusing on contemporary print and digital media. This can be, indeed, a stimulating way of studying how "era styles" (Steimberg 1998) evolve in cultures and shape them.

\section{Acknowledgements}

We thank the cartoonists who kindly spent time completing our questionnaire and sending a representative cartoon of their style, especially the six cartoonists who provided authorisation to publish their work in this paper. We are also grateful to Constanza Zinkgräf for her careful reading of the draft of the manuscript, as well as to two anonymous reviewers' helpful and finely tuned feedback.

This study was partly sponsored by the following projects: Agencia Nacional de Promoción Científica y Tecnológica PICT 2014-2929, PIP CONICET 0142, Universidad Nacional del Comahue C-130. A partial version of this paper was presented at the $29^{\text {th }}$ Conference of the International Society for Humour Studies held in Montréal, on July 10-14, 2017. 


\section{Notes}

1. The analysis of the enunciative level is beyond the scope of the present study.

2. Jacques-Marie Boyer-Brun was a royalist journalist from Nîmes (France), who launched a publication in leaflets, Histoire des caricatures de la révolte des Français. According to Duprat (2004), he had both a pedagogical and an ideological goal: to present some of the most successful patriotic cartoons, to explain the signs used and the context, as well as to vilify and show the misdeeds of the Revolution.

3. Thirteen of the cartoonists did not choose any representative piece of their work, four of them chose strips - which we decided to exclude from the corpus for the sake of format homogeneity, given that the rest were single-panel cartoons-while six cartoonists chose two cartoons, and two selected three cartoons.

4. We have had access to these statements in the context of questionnaires and interviews held with cartoonists from all over the world: see section 3.1.

\section{Appendix}

In what follows, cartoonists' explanations are fully transcribed in the original language, followed by the English translation. The complete set of responses highlights the interest that first-person perspective data offers in order to achieve an integrated panorama of cartoons' genre and subgenres taking different semiotic levels into account. Such analyses are the focus of upcoming works.

Savignac (Figure 2):

"Le massacre de la place Tien an Men en Chine en 1989. En Chine, on utilise de l'encre de Chine. Ici, le flacon est renversé et l'encre coule comme du sang. Mais elle est rouge. Elle dessine, en tombant de l'encrier, une carte de la Chine. Il n'y a pas de bulle, pas de texte. Le dessin est simple".

"The massacre of Tian'anmen in China in 1989. In China, Chinese ink is used. Here, the bottle is spilled and the ink flows like blood. But it is red. The red ink draws, in the fall of the inkwell, a map of China. There is no bubble, no text. The drawing is simple".

Kap (Figure 3):

"Creo que el resumen de lo que intento que sea mi estilo sería: explicar una situación compleja con el mínimo de palabras y con un punto de humor".

"I think the summary of what I intend my style to be would be: to explain a complex situation with the minimum of words and with a point of humour".

Kichka (Figure 4):

"Dessin réalisé pour la sortie du Tintin de Spielberg. Thème choisi car en relation avec mes racines belges. Déconstruction de l'icône Tintin, vieilli, et Milou mort. Jeu de mots 'adopter' et 'adapter'. (Tintin est orphelin depuis la mort de son géniteur Hergé)".

"Cartoon made for the release of Spielberg's Tintin. Theme chosen due to my Belgian roots. Deconstruction of the icon Tintin, aged, and Milou dead. Play on words 'adopt' and 'adapt'. (Tintin is an orphan since the death of his parent Hergé)".

Gai (Figure 5):

"Envío uno, de mi último libro: "Ojo en tinta", 2012. Lo elegí porque creo que sintetiza esa búsqueda que no siempre se logra: Una mirada distinta, una mirada crítica, poco texto (o 
ninguno), una presentación gráfica atractiva, creo, para el lector".

"I send a cartoon from my last book: 'Eye in ink', 2012. I chose it because I think it synthesizes that search that is not always achieved. A different look, a critical look, scarce text (or none), and what I consider to be an attractive graphic presentation for the reader".

Pepe San Martín (Figure 6): He chose two cartoons and the explanation he provided corresponds to the other cartoon not published in this paper. For this reason we do not include it here.

\section{Biratan (Figure 7):}

"Sou essencialmente um desenhista de humor. Gosto de fazer cartoons. Fazer rir, alegrar as pessoas, os leitores. Este em particular, gosto muito. 'Os Vizinhos'. Acho que é uma relação com infinitas situações inspiradoras para o desenhista de humor".

"I'm essentially a humorous cartoonist. I enjoy making cartoons. To make people laugh, to make people, readers, happy. This one in particular was very appreciated. 'The neighbours'. I think it is a relationship with endless inspiring situations for a humorous cartoonist.

\section{References}

Agüero Guerra, M. (2013). 'Análisis semántico-cognitivo del discurso humorístico en el texto multimodal de las viñetas de Forges'. ELUA 27, pp. 7-30.

Agüero Guerra, M. (2016). 'Beyond verbal incongruity: A genre-specific model for the interpretation of humour in political cartoons', in Ruiz-Gurillo L. (ed.), Metapragmatics of Humour: Current Research Trends, Amsterdam: John Benjamins, pp. 57-79.

Al Masri, H. (2016). 'Jordanian editorial cartoons: A multimodal approach to the cartoons of Emad Hajjaj'. Language \& Communication 50, pp. 45-58.

Attardo, S. (1994). Linguistic Theories of Humour. Berlin: Mouton de Gruyter.

Attardo, S. (1997). 'Semantic foundations of cognitive theories of humour'. Humour: International Journal of Humour Research 4(10), pp. 395-420.

Attardo, S. (2001). Humorous Texts: A Semantic and Pragmatic Analysis. Berlin/New York: Mouton de Gruyter.

Attardo, S. \& Raskin, V. (1991). 'Script theory revis(it)ed: Joke similarity and joke representation model'. Humour: International Journal of Humour Research 4 (3/4), pp. 293- 347.

Attardo, S., Hempelmann, C. F. \& Di Maio, S. (2002). 'Script oppositions and logical mechanisms: Modelling incongruities and their resolutions'. Humour: International Journal of Humour Research 15(1), pp. 3-46.

Bakhtin, M.M. (1986). Speech Genres and Other Late Essays. Austin: University of Texas Press.

Beguin-Verbrugge, A. (2006). Images en texte, Images du texte. Dispositifs graphiques et communication écrite. Villeneuve d'Ascq: Presses Universitaires de Septentrion.

Bergson, H. (1911). Laughter: An Essay on the Meaning of the Comic. New York: Macmillan. Beth, A. \& Marpeau, E. (2005). Figures de style. Paris: Librio Mémo.

Bivins, T. H. (1984). 'Format preferences in editorial cartooning'. Journalism and Mass Communication Quarterly 61(1), pp. 182-185.

Bounegru, L. \& Forceville, C. (2011). 'Metaphors in editorial cartoons representing the global financial crisis'. Visual Communication 10, pp. 209-229.

Charaudeau, P. (2006). 'De nouvelles catégories pour l'humour?'. Questions de Communication 10, pp. 19-41. 
Compagnon, A. (2001). Théorie de la littérature : la notion de genre. Lecture from Paris IV Paris-Sorbonne University, UFR de Littérature française et comparée. Retrieved August 22, 2017 from http://www.fabula.org/compagnon/genre.php.

Conradie, M., Brokensha, S. \& Pretorius M. (2012). 'No small irony: A discourse analysis of Zapiro's 2010 World Cup cartoons'. Language Matters: Studies in the Languages of Africa 43(1), pp. 39-59.

Curti, S. (2006). Dessin d'actualité et représentation de l'imaginaire politique : approche sémio-rhétorique d'un corpus de presse (les élections présidentielles de 2002 en France). Doctoral thesis on Language sciences, didactics and semiotics. Besançon: Franche-Comté University.

Denzin, N. K. \& Lincoln, Y. S. (2005). The SAGE Handbook of Qualitative Research. Thousand Oaks: Sage Publications.

Duprat, A. (2002). Les rois de papier. La caricature de Henri III à Louis XVI. Paris: Belin.

Duprat, A. (2004). 'Le regard d'un royaliste sur la Révolution : Jacques-Marie Boyer de Nîmes'. Annales historiques de la Révolution française 337, pp. 21-391.

Duval, S. \& Martinez, M. (2000). La satire. Paris: Armand Collin.

Edwards, J.L. (1997). Political Cartoons in the 1988 Presidential Campaign: Image, Metaphor and Narrative. New York: Garland.

El Refaie, E. (2003). 'Understanding visual metaphor: the example of newspaper cartoons'. Visual Communication 2(1), pp. 75-95.

El Refaie, E. (2005). “Our purebred ethnic compatriots": irony in newspaper journalism'. Journal of Pragmatics 37, pp. 781-797.

El Refaie, E. (2009). 'Multiliteracies: how readers interpret political cartoons'. Visual Communication 8(2), pp. 181-205.

Forceville, C. (2002). 'The identification of target and source in pictorial metaphors'. Journal of Pragmatics 34(1), pp. 1-14.

Forceville, C. (2006). 'Non-verbal and multimodal metaphor in a cognitivist framework: Agendas for research', in Kristiansen G., Achard, M., Dirven, R., \& Ruiz de Mendoza Ibáñez, F. J. (eds), Cognitive Linguistics: Current Applications and Future Perspectives, Berlin: Mouton de Gruyter, pp. 379-402.

Forceville, C. (2016). 'Theories of conceptual metaphor, blending, and other cognitivist perspectives on comics', in Cohn N. (ed.), The Visual Narrative Reader, London: Bloomsbury, pp. 89-114.

Forceville, C. \& Urios Aparisi, E. (2009). Multimodal Metaphor. Berlin/New York: Mouton de Gruyter.

Freud, S. (1928). 'Humour'. International Journal of Psychoanalysis 9, pp. 1-6.

Fromilhague, C. (1995). Les figures de style. Paris: Nathan.

Goossens, L. (1990). 'Metaphtonymy: the interaction of metaphor and metonymy in expressions for linguistic action'. Cognitive Linguistics 1(3), pp. 323-340.

Greenacre, M. (1984). Theory and Applications of Correspondence Analysis. London: Academic Press.

Groupe Mu. (1978). 'Ironie et iconique'. Révue Poétique 36, pp. 427-442.

Groupe Mu. (1992). Traité du signe visuel. Pour une rhétorique de l'image. Paris: Seuil.

Harrison, R. P. (1981). The Cartoon: Communication to the Quick. Beverly Hills: Sage Publications.

Harvey, K. C. (2009). 'How comics came to be: through the juncture of word and image from magazine gag cartoons to newspaper strips, tools for critical appreciation plus rare seldom witnessed historical facts', in Heer J. \& Worcester K. (eds), A Comics Studies Reader, Jackson: University Press of Mississippi, pp. 25-45. 
Houdebine-Gravaud, A.-M. (2013). 'De la parodie dans la caricature et le dessin de presse (entre intertextualité, interdiscursivité et intericonicité', in Vivero García, M. D. (dir), Frontières de l'humour, Paris: L'Harmattan, pp. 59-89.

Hutcheon, L. (1985). A Theory of Parody. The Teachings of Twentieth-century art forms. New York: Methuen.

Jewitt, C. (2011). The Routledge Handbook of Multimodal Analysis. New York: Routledge.

Kerbrat-Orecchioni, C. (2013). 'L'ironie: problèmes de frontière et étude de cas. Sarkozy face à Royal (2 mai 2007)', in Vivero García M. D. (dir), Frontières de l'humour, Paris: L'Harmattan, pp. 23-62.

Kress, G. (2010). Multimodality: A Social Semiotic Approach to Contemporary Communication. London: Taylor \& Francis.

Kress, G. \& van Leeuwen, T. (2006). Reading Images: The Grammar of Visual Design. New York: Routledge.

Lockyer, S. (2006). 'Heard the one about... Applying mixed methods in humour research?'. International Journal of Social Research Methodology 9(1), pp. 41-59.

Martinec, R. \& Salway, A. (2005). 'A system for image-text relations in new (and old) media'. Visual Communication 4 (3), pp. 337-371.

Negro Alousque, I. (2013). 'Visual metaphor and metonymy in French political cartoons'. Resla 26, pp. 365-384.

Negro Alousque, I. (2014). 'Pictorial and verbo-pictorial metaphor in Spanish political cartooning'. Círculo de Lingüística Aplicada a la Comunicación 57, pp. 59-84.

Pedrazzini, A. (2011). La construction de l'image présidentielle dans la presse satirique : vers une grammaire de l'humour. Jacques Chirac dans l'hebdomadaire français Le Canard enchaîné et Carlos Menem dans le supplément argentin Sátira/12. Doctoral thesis on Information and Communication Sciences. Paris IV Paris-Sorbonne University, Esorbonne. URL: www.theses.fr/2010PA040203.pdf

Pedrazzini, A. \& Scheuer, N. (2010). 'La interacción lingüística e ícono-plástica en la producción de caricaturas políticas: un estudio funcional y retórico'. IRICE Nueva época 21, pp. 95-111.

Pedrazzini, A. \& Scheuer, N. (2012). 'Figuras retóricas verbales y visuales en la conformación de un estilo de autor: las caricaturas políticas del semanario satírico francés Le Canard enchaîné'. Cultura, lenguaje y representación X, pp. 111-128.

Pedrazzini, A. \& Scheuer, N. (2017). 'La geografía del humor gráfico actual: tensiones entre lo local y lo trans-cultural', in Flores, A. B. (coord). El rumor del humor: Jornadas de Investigación: innovación, rupturas y transformaciones en la cultura humorística argentina. Córdoba: Universidad Nacional de Córdoba, pp. 137-162.

Pedrazzini, A. \& Scheuer, N. (forthcoming). Modal functioning of rhetorical resources in selected multimodal cartoons.

Ruiz de Mendoza Ibáñez, F. J. \& Mairal Usón, R. (2007). 'High-level metaphor and metonymy in meaning construction', in Radden, G., Köpcke K-M., Berg, T. \& Siemund, P. (eds). Aspects of Meaning Construction, Amsterdam/Philadelphia: John Benjamins, pp. 33-51.

Saraceni, M. (2003). The Language of Comics. London: Routledge.

Serafini, F. (2013). Reading the Visual: An Introduction to Teaching Multimodal Literacy. New York: Teachers College Press.

Schilperoord, J. \& Maes, A. (2009). 'Visual metaphoric conceptualisation in editorial cartoons', in Forceville Ch. \& Urios Aparisi E. (eds.), Multimodal Metaphor, Berlin/New York: Mouton de Gruyter, pp. 213-240.

Schoentjes, P. (2001). Poétique de l'ironie. Paris: Seuil. 
Segre, C. (1985). Introduction to the Analysis of the Literary Text. Bloomington: Indiana University Press.

Shelton Caswell, L. (2004). 'Drawing swords: War in American editorial cartoons'. American Journalism 21(2), pp. 13-45.

Shultz, K. \& Germeroth, D. (1998). 'Should we laugh or should we cry? John Callahan's humour as a tool to change societal attitudes toward disability'. Howard Journal of Communications 9(3), pp. 229-244.

Steimberg, O. (1998). Semiótica de los medios masivos. El pasaje a los medios de los géneros populares. Buenos Aires: Atuel.

Steimberg, O. (2013). 'Sobre algunos temas y problemas del análisis del humor gráfico', in Leyendo historietas. Textos sobre relatos visuales y humor gráfico, Buenos Aires: Eterna Cadencia, pp. 172-192.

Steuter, E. \& Willis, D. (2011). 'Drawing dehumanisation: Exterminating the enemy in editorial cartoons', in Dente Ross, S. \& Martin Lester, P. (eds). Images that Injure: Pictorial Stereotypes in the Media, Santa Bárbara: Praeger, pp. 322-336.

Strauss, A. \& Corbin, J. (1998). Basics of Qualitative Research Techniques and Procedures for Developing Grounded Theory. London: Sage Publications.

Suls, J. M. (1972). 'A two-stage model for the appreciation of jokes and cartoons: an information-processing analysis', in Goldstein, J. \& McGhee, P. (eds.), The Psychology of Humour: Theoretical Perspectives and Empirical Issues, New York: Academic Press, pp. 81-100.

Templin, C. (1999). 'Hillary Clinton as threat to gender norms: cartoon images of the First Lady'. Journal of Communication Inquiry 23, pp. 20-36.

Thivolet, M. (1996). 'Caricature'. Paris: Encyclopaedia Universalis, pp. 1016-1023.

Tillier, B. (2005). À la charge! La caricature en France de 1789 à 2000. Paris: Les Éditions de l'Amateur.

Tsakona, V. (2009). 'Language and image interaction in cartoons: Towards a multimodal theory of humour'. Journal of Pragmatics 41, pp. 1171-1188.

Verón, E. (1992). 'Reading is doing: Enunciation in the discourse of the print media'. Marketing Signs 14-15, pp.1-12.

Vilches, L. (1984). La lectura de la imagen. Prensa, cine, televisión. Barcelona: Paidós.

Walker, M. (1978). Daily Sketches: A Cartoon History of Twentieth Century Britain. London: Frederick Muller.

Ward, J. (1963). 'Hierarchical grouping to optimize an objective function'. Journal American Statistic Association 58, pp. 236-244.

Werner, W. (2004). 'On political cartoons and social studies textbooks: Visual analogies, intertextuality, and cultural memory'. Canadian Social Studies 38(2), pp. 1-10.

Ying-Yu Lin, T. \& Chiang, W. (2015). 'Multimodal fusion in analysing political cartoons: Debates on U.S. beef imports into Taiwan'. Metaphor and Symbol 30(2), pp. 137-161.

Yus, F. (2009). 'Visual metaphor versus verbal metaphor: A unified account', in Forceville, C. \& Urios Aparisi, E. (eds.), Multimodal Metaphor, Berlin/New York: Mouton de Gruyter, pp. 147-172.

Zecchetto, V. (2006). La danza de los signos. Nociones de semiótica general. Buenos Aires: La Crujía. 